\title{
Phytochemical screening and antifungal potency of Vernonia amygdalina (bitter leaf) extract against post harvest mycodeterioration of tomato (Lycopersicum esculentum)
}

\section{U. N. Emiri ${ }^{1}$ and E. B. Enaregha ${ }^{2}$}

${ }^{1}$ Isaac Jasper Boro College of Education. Department of Agricultural Education. Sagbama. Bayelsa State. Nigeria. Email: ucheemiri@gmail.com

${ }^{2}$ Isaac Jasper Boro College of Education. Department of Biology Education. Sagbama. Bayelsa State. Nigeria.

\begin{abstract}
The study investigated fungi associated with post harvest tomato fruits sold in the open market in Port Harcourt Metropolis. The antifungal activity (bitter leaf) extracts against spoilage was studied using well-in-agar diffusion method. Results showed that mean percentage incidence of fungi isolated from tomato fruits were Rhizopus stolonifer (56\%), Aspergillus niger (62\%) and Altermaria altermata (35\%). Aqueous and ethanolic extracts of Vernonia amygdalina at different concentrations $(20 \%, 40 \%$, and $60 \%)(\mathrm{w} / \mathrm{v})$ were used against fungi isolates, while water and ketoconzole $(0.5 \mathrm{mg} / \mathrm{mL})$ served as negative and positive control, respectively. Aqueous and ethanolic extracts of $V$. amygdalina inhibited the growth of all three test fungi. There were significant differences $(p<0.05)$ in the mean inhibitory effects of plant extracts and control. Antifungal activity measured as diameter of zone of inhibition revealed that $V$. amygdalina acqueous extract at $60 \%$ was very active against Aspergillus niger $(16.50 \mathrm{~mm})$ and Alternaria altermata $(16.00 \mathrm{~mm})$, while being moderately active against Rhizopus stolonifer $(13.00 \mathrm{~mm})$. However, $60 \%$ ethanolic extract of $V$. amygdalina was very active against $A$. niger $(19.00 \mathrm{~mm}), A$. altermata $(17.00 \mathrm{~mm})$ and Rhizopus stolonifer $(15.80 \mathrm{~mm})$. Phytochemical screening of $V$. amygdalina revealed the presence of tannins, oxalate, saponnins, flavanoid, cynogenic glucoside, phytate and Alkaloids V. amygdalina could serve as a potentially viable alternative to chemical fungicides in the preservation of post harvest tomato fruits (Lycopersicum esculentum).
\end{abstract}

Keywords: Tomato; Vernonia amygdalina; Port harvest; Fungi; Phytochemical.
Received

September 14, 2020

Accepted

November 30, 2020

Released

December 31, 2020

Full Text Article

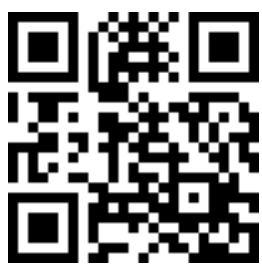

ORCID

(C) 0000-0003-2964-8970

U. N. Emiri

(D) $0000-0002-9213-6129$

E. B. Enaregha 


\section{Introduction}

Post harvest are diseases responsible for heavy losses of agricultural produce during storage, reduce food quality and render them unfit for human consumption (Doyle, 2007). Micro organisms, particularly fungi are adjudged the most notorious culprits, among other factors, responsible for post harvest diseases of crops (Ray et al., 2000). Some fungi implicated in post harvest diseases are able to produce mycotoxins known to be highly toxic, carcinogenic and are able to suppress one's immune system (Bankole et al., 2005). Seeking ways to effectively control post harvest spoilage of agricultural produce is therefore undeniably essential, especially for crops such as Tomato that are widely consume in Nigeria and other parts of the world.

Tomato (Lycopersicum esculentum) is a widely consumed fruit eaten in both raw and processed forms. (Moneruzzaman et al., 2008). It is rich in lycopene, vitamins A and C, carbohydrates, proteins, fats, fibres and potassium (Talvas et al., 2010).

The consumption of tomatoes throughout the world is believed to benefit the heart and other organs. It is on record that the richest source of lycopene is tomato and tomatobased products (Evangelia et al., 2005). Lycopene has been found to prevent prostrate cancer, improve the skin's ability to protect itself against the harmful ultra violet rays, decrease the risk of breast, lungs, stomach, bladder, uterine, head and neck cancers, protect against neurodegenerative diseases, lower urinary tract infections and reduce the cardiovascular risk associated with type 2 diabetes (Shidfar et al., 2010; Zdenka et al., 2010; Borguini et al., 2009; Zhang et al., 2009).

Tomato contains large amount of water which makes it more susceptible to spoilage by the action of micro-organisms. (Bai and Lindhout, 2006). These microorganisms attack is one of the limiting factors that influence tomato economic value as well reduce its shelf life.

Fungi have been reported as the source of spoilage of most of the tomato samples accessed than bacteria. (Gosh, 2009). Earlier workers reported fungi implicated in tomato spoilage. Some of which include Aspergillus phoenics, Trichoderma spp, Alternaria altermata, Fusarium spp, Aspergilus niger, Mucor spp, Rhizopus stolonifer, Penicillium spp, and Geotrichum spp. (Etebu et al., 2013, John et al., 2016; Chuku et al., 2010). Some of these fungi have been recognized as a source of potential health hazard (Bankole et al., 2005).There is therefore the need to seek ways that would control the proliferation of potential harmful spoilage fungi associated with the fruit.

The use of synthetic chemicals in the preservation post-harvest agricultural produce in storage has proven over the years to be very effective in controlling pathogenic fungi (Manczinger et al., 2002). However, their use is increasingly becoming undesirable because they are themselves carcinogenic, teratogenic, highly toxic with long degradation periods and are able to induce chemical poisoning, as well as fungal resistance (Adegoke et al., 2002). As a result, the search for post-harvest control strategies has recently been directed towards the use and implementation of natural preservatives that may have a positive effect on human health (WHO, 2002).

Amongst natural preservatives, the use of natural essential oils obtained from plants, particularly medicinal plants has been promising. They have been shown to reduce microbial and chemical spoilage among agricultural produce with no proven detrimental effect on human and the environment even at high concentration (Pessoa et al., 2002).These botanicals of medicinal importance have been proven to be very effective against fungal infection even where treatments with synthetic antibiotics failed (Oshim et al., 2016). One of such proven botanicals is Vernonia amygdalina (bitter leaf).

Bitter leaf is a shrub that grows abundantly throughout all African countries, and possibly in the torrid zones of the Caribbean Islands. It is efficacious as a medicine, it is an antidote for malaria, it is also anti-bacteria and anti-parasites (Challand and Willcox, 
2009). The roots and the leaves when taken in any form detoxifies the blood, prevents rheumatism, indigestion, scurvy and counters the effects of excess sugar in the blood stream (Challand and Wilcox, 2009). Fashola et al. (2011) reported that V. amygdalina has hypoglycaemic activity. They observed a close dependent reduction in fasting blood sugar level in alloxan induced diabetic rats after treatment with different concentrations of the aqueous leaf extracts.

Extracts of bitter leaf have been shown by numerous workers to control microbial infections and aflatoxin contamination of food commodities (Suleiman et al., 2008; Audu et al., 2016; John et al., 2016; Onyeani et al., 2020). In this work, fungi associated with post harvest tomato fruits sold in the open market in Port Harcourt metropolis is being studied and the efficacy of inhibitory properties of Vernonia amygdalina (aqueous and ethanolic) leaf extracts against spoilage fungi isolated from tomato was also studied.

\section{Materials and methods}

\section{Experiment 1: Survey of post harvest quality of tomato fruits}

Ten tomato fruits samples were purchased from Woji market in Port Harcourt, Rivers State, Nigeria. They were transported to the Microbiology Laboratory of Rivers State University, Port Harcourt, in sterile polythene bags for fungal isolation. The samples were left for five days for spoilage to occur. The ten partially rotted tomato fruits were used for the study (Figure 1).
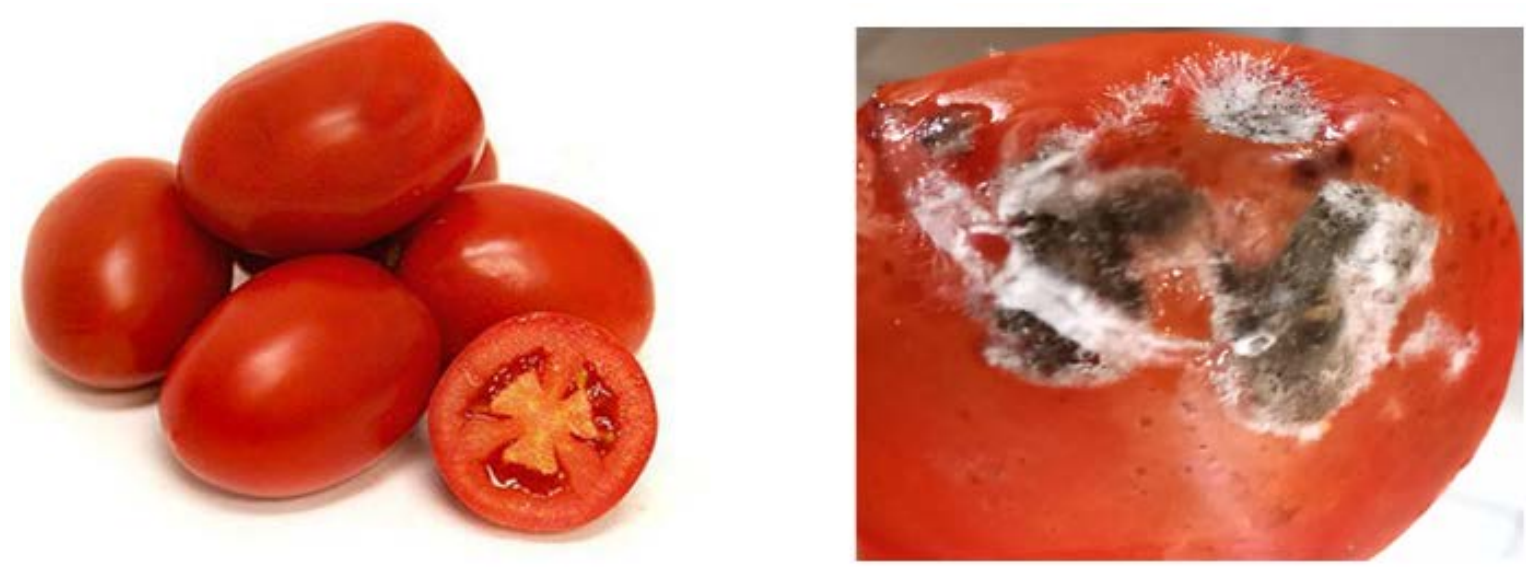

Figure 1. Healthy tomato fruits (left) and fungal infected tomato fruit (right).

\section{Samples processing}

Each of the partially rotted tomato fruits was carefully cut with the aid of a sterile scalpel and enriched in sterile Sabouraud Dextrose Broth for $24 \mathrm{~h}$. Ten fold serial dilutions of the sample were thereafter carried out.

\section{Isolation of fungi}

The pour plate method was used. One milliliter of the serially-diluted sample was dispensed into a conical flask containing sterile Sabouraud Dextrose Agar (SDA) and two percent chloramphenicol to inhibit bacterial growth. The contents were properly mixed and dispensed aseptically into sterile petri-dishes, 
incubated at $28{ }^{\circ} \mathrm{C}$ for five days. The colonies that developed were counted and sub cultured repeatedly on Sabouraud Dextrose Agar plates to obtain pure cultures.

Mean percentage incidence of fungi was calculated using the formula:

Mean percentage $=\frac{\text { Total number of occurence of a particular fungi }}{\text { Total number of plated sample }} X \frac{100}{1}$

\section{Characterization and identification of the isolates}

The pure cultures of the fungi were identified on the basis of their colony growth pattern, conidial morphology and pigmentation using the slide culture technique and microscopic examination. The identity of each fungus was confirmed with the aid of a mycological atlas.

\section{Pathogenicity test of the isolates}

The procedures of Agrios (2005) was used. Five healthy tomatoes were properly washed with tap water, rinsed with distilled water and surface-disinfected with ethanol. Sterile cork borers were used to bore holes in each of the tomato fruits. Each of the isolated fungi was thereafter inoculated into the fruits after which the cores of the fruits were replaced. Sterile petroleum jelly was used to seal the holes of the fruits to prevent contamination. Five tomatoes fruits wounded with the cork borers but were not inoculated with the fungi served as controls.

The inoculated tomato fruits and the control were placed in sterile polythene bags (one fruit per bag). Each of the fruits was moistened with wet balls of absorbent cotton wool to create a humid condition. The fruits were thereafter incubated at $28^{\circ} \mathrm{C}$ for five days and observed for spoilage. The fungi were re-isolated from the fruits and compared with the original isolates. The fungi isolated from the partially rotted tomato fruits were Rhizopus stolonifer, Aspergillus niger and Alternaria altermata.

\section{Experiment 2: Anti-fungal potency of $V$. amygdalina (bitter leaf) extracts against fungal spoilage of tomato fruits}

The inhibitory effect of aqueous and ethanolic leaf extract $V$. amygdalina on growth of three test fungi; Aspergillus niger, Rhizopus stolonifer and Alternaria altermata previously isolated from post harvest tomato fruits was studied, using the well-in-agar diffusion method. Leaves of $V$. amygdalina were collected from a garden in Port Harcourt of Rivers State, Nigeria and washed thoroughly under running water and further with sterile distilled water, after which they were air dried for 10 days. The leaves thereafter were ground into powder using a vegetable blender.

\section{Sample extraction (aqueous extract)}

Three quantities $(20 \mathrm{~g}, 40 \mathrm{~g}$, and $60 \mathrm{~g}$ ) of the leaf powder were measured and each dissolved in $100 \mathrm{~mL}$ of sterile distilled water to obtain $20 \%, 40 \%$ and $60 \%(\mathrm{w} / \mathrm{v}$ ) aqueous extracts and mixed vigorously after which the plant residue was filtered through a sterile muslin cloth and the obtained filtrate was further sterilized by filtration through the membrane filter. The sterile extracts obtained were then stored in sterile capped McCartney bottles and refrigerated at $4{ }^{\circ} \mathrm{C}$ until use

\section{Extraction using ethanol (ethanolic extract)}

$20 \mathrm{~g}, 40 \mathrm{~g}$ and $60 \mathrm{~g}$ of the leaf powder were each dissolved in $100 \mathrm{~mL}$ of $70 \%$ ethanol for $24 \mathrm{~h}$, to obtain $20 \%, 40 \%$ and $60 \%(\mathrm{w} / \mathrm{v})$ ethanol extract at room temperature with 
occasional stirring. The content was filtered with muslin cloth and evaporated to dryness in a water bath at $78{ }^{\circ} \mathrm{C}$. The extracts were collected and stored in sterile McCartney bottles and refrigerated at $4{ }^{\circ} \mathrm{C}$ until required for use.

\section{Phytochemical analysis}

The phytochemical analysis of the $V$. amygdalina leaf was done according to the procedure of AOAC (2005).

\section{Sterility test of plant extracts}

Each of the extracts (aqueous and ethanol) was tested for sterility after sterilization by inoculating $1 \mathrm{ml}$ of each extract on sterile Sabouraud Dextrose Agar (SDA) and incubated at $37^{\circ} \mathrm{C}$ for $24 \mathrm{~h}$. The plates were observed for growth. No growth was observed after incubation, which indicates the extracts were sterile.

\section{Determination of anti-fungal potency of various crude extract}

Sabouraud Dextrose Agar (SDA) was prepared according to manufacturer's prescription, integrated with chloramphenicol. Three media plates were separately inoculated with suspension of the test organisms; Rhizopus stolonifer, Aspergillus niger and Alternaria altermata respectively, to obtain pure culture of each by spread plate method in three replicates, incubated at room temperature for 7 days. Thereafter, a sterile cork borer (8 mm diameter) was used to bore hole in each of the pure culture plates. Thereafter $1 \mathrm{~mL}$ each of the $20 \%, 40 \%$ and $60 \% \mathrm{~V}$. amygdalina aqueous plant extract was dispensed into the hole on each plate. The plates were allowed to stand for $30 \mathrm{~min}$ for diffusion of the extract to occur and then incubated at room temperature for 5 days. This procedure was repeated for ethanolic plant extracts, distilled sterile water and ketoconazole which served as negative and positive control, respectively.

The inhibitory effect of the test plant extracts and control treatments were ascertained by a clear zone of inhibition of fungal growth around the well after 5 days of incubation. Data obtained were subjected to statistical analysis using ANOVA. Mean diameter of zones of inhibition were further subjected to LSD means separation test.

\section{Results}

Tomato fruits sold in Port Harcourt, Rivers State Nigeria, were infected by postharvest spoilage fungi (Table 1).

Table 1. Mean percentage incidence of fungi isolated from tomato fruit.

\begin{tabular}{|l|c|}
\hline Fungal isolated & Tomato (Lycopersicum esculentum) \\
\hline Rhizopus stolonifer & $56 \pm 0.37$ \\
\hline Aspergillus niger & $62 \pm 0.30$ \\
\hline Alternaria altermata & $35 \pm 0.32$ \\
\hline
\end{tabular}

The results on effect (inhibitions) of different concentrations of aqueous extracts showed there was significant increase in zone of inhibition as the concentration of the extracts increased. $R$. stolonifer had the least inhibition while A. niger had the highest diameter of inhibition across the different rates of concentration of plant extract (Table 2). 
Table 2. Comparative mean effect (inhibition) of different concentrations of aqueous extracts of V. amygdalina on fungal growth.

\begin{tabular}{|l|c|c|c|}
\hline \multirow{2}{*}{ Treatment concentration } & \multicolumn{3}{|c|}{ Diameter of zone of inhibition (mm) } \\
\cline { 2 - 4 } & R. stolonifer & A. niger & A. altermata \\
\hline Extract $(20 \%)$ & 11.00 & 12.00 & 11.50 \\
\hline Extract $(40 \%)$ & 11.80 & 14.00 & 13.00 \\
\hline Extract $(60 \%)$ & 13.00 & 16.50 & 15.00 \\
\hline Water & 0.00 & 0.00 & 0.00 \\
\hline Ketoconazole $(0.5 \mathrm{mg} / \mathrm{mL})$ & 75.00 & 80.00 & 80.00 \\
\hline LSD $(\mathrm{P} \leq 0.05)$ & 1.08 & 0.79 & 1.28 \\
\hline
\end{tabular}

Means are significantly different LSD at $\mathrm{p} \leq 0.05$.

Similar observation was made with ethanolic extracts, $R$. stolonifer showed least inhibition compared to other fungal isolates (Table 3).

Table 3. Comparative mean effect (inhibitions) of different concentrations of ethanol extracts of V. amygdalina on fungal growth.

\begin{tabular}{|l|c|c|c|}
\hline \multirow{2}{*}{ Treatment concentration } & \multicolumn{3}{|c|}{ Diameter of zone of inhibition (mm) } \\
\cline { 2 - 4 } & R. Stolonifer & A. sniger & A. altermata \\
\hline Extract $(20 \%)$ & 11.90 & 15.00 & 13.50 \\
\hline Extract $(40 \%)$ & 14.00 & 17.00 & 16.00 \\
\hline Extract $(60 \%)$ & 15.80 & 19.00 & 17.00 \\
\hline Water & 0.00 & 0.00 & 0.00 \\
\hline Ketoconazole $(0.5 \mathrm{mg} / \mathrm{mL})$ & 75 & 80 & 80 \\
\hline LSD $(\mathrm{p} \leq 0.05)$ & 0.76 & 0.92 & 1.00 \\
\hline
\end{tabular}

Means are significantly different LSD at $\mathrm{p} \leq 0.05$.

The results of the phytochemical constituents of $V$. amygdalina leaf is presented in Table 4.

Table 4. Phytochemical constituents of Vernonia amygdalina leaf.

\begin{tabular}{|l|c|}
\hline Fungal isolated & Tomato (Solanum lycopersicum) \\
\hline Tannins & $10.26 \pm 0.03$ \\
\hline Oxalate & $3.08 \pm 0.12$ \\
\hline Saponins & $6.17 \pm 0.05$ \\
\hline Flavonoid & $4.69 \pm 0.08$ \\
\hline Cynogenic glucoside & $2.11 \pm 0.02$ \\
\hline Phytate & $4.43 \pm 0.03$ \\
\hline Alkaloids & $5.75 \pm 0.06$ \\
\hline
\end{tabular}

The phytochemical screening revealed that the leaf of $V$. amygdalina has appreciable amount of tannins, saponins, alkaloids and flavonoid relatively higher than 
phytate, oxalate, and cynogenic glucoside. However, ethanolic extracts appeared to have more inhibitory effect on all test fungi, relative to aqueous extracts.

\section{Discussion}

Results on the fungi implicated with the mycodeterioration of post-harvest tomato fruits sold in the open market in Port Harcourt, Nigeria revealed Rhizopus stolonifer, Aspergillus niger, Alternaria altermata. These fungi have been reported by earlier workers to be consistently associated with post harvest rot of tomatoes during storage (Chuku et al., 2010; Etebu et al., 2013; Ugwu et al., 2014; John et al., 2016). Deductions from the incidence of these organisms revealed that $A$. niger had higher incidence followed by $R$. stolonifer, while Alternaria altermata had the least incidence. The high incidence recorded by $A$. niger and $R$. stolonifer was not unexpected as fungi thrive in moisture, hence tomato fruit (rich in moisture) provided a good substrate for the fungi. Aspergillus species are known to produce several toxic metabolites, mycotoxins which is a very important toxin known to pose hazard on human and animal health (Bankole, 2005).

It has been revealed from this study that the plant extract possess anti-fungal properties, however ethanol extract appeared to be more potent than aqueous extracts because ethanol extracts produced higher diameter of inhibition among all the test fungi as shown in Table 2 and 3. It thus suggests that ethanolic extract possess more anti microbial activities than aqueous extract. $R$. stolonifer had the lowest diameter of inhibition, while Aspergilus niger had the highest diameter of inhibition, which suggest that $A$. niger is more suspectible to the plant extract especially ethanolic extract. This observation is in consonance with the report of Adetunji et al. (2013) and Audu et al. (2018). However, this result negates the assertion of John et al. (2016) who reported that $R$. stolonifer was more susceptible to ethonolic $V$. amygdalina extract. The potency of ethanolic extract over aqueous extract could be attributed to the better solubility of the active components in organic solvents (de Boer et al., 2005; Doughari et al., 2007). The presence of phytochemicals, tannins, oxalate, saponins, flavonoids, cynogenic glucoside, phytate, and alkaloids in the extracts of $V$. amygdalina is comparable to the findings of Audu et al. (2018) and Udochukwu et al. (2015). These petrochemicals in V. amagdalina extracts may explain the reason for its anti-microbial actions, as have been previously documented (Nenaah, 2013; Jasim et al., 2015; Al-Habi et al., 2017; Jin et al., 2017).

The fungal inhibitory effect of aqueous and ethanolic extracts of $V$. amygdalina in this study was observed to be dose dependent. This pattern of correspondingly greater diameter of zone of inhibition with respect to increase in concentration of the plant extract was similar to the results reported by several other workers (Ijato, 2011; Etebu and Emiri, 2016; John et al., 2016; Chuku and Emiri, 2019). These workers separately reported that an increase in the concentration of an antimicrobial plant extract achieved a better result in the control of pathogenic fungi.

In a similar development, antifungal effectiveness of some tropical plants extracts in controlling several plant pathogens have been reported by several researchers (Amadioha, 2000; Okigbo and Ikediugwu, 2000; Okigbo and Nmeka, 2005). Results from this work agrees with the report of Etebu and Emiri (2016) which showed the inhibitory effect of Ocimum gratissimum against Aspergilu spp. Ijato et al. (2011) reported that Chromolaena odorata (leaf), Tridax procumbens (leaf), Vernonia amygdalina achieved an inhitory effect of $54.58 \%$ on the radial growth of rot fungi. Ugwuoke et al. (2008) reported the use of $V$. amygdalina in the control of Fusarium solani causing tuber rot on cocoyam. The observations of these researchers agree with this present study.

The result from this work suggest that $V$. amygdalina may be more effective if used in the control of post harvest diseases occasioned by Aspergillus spp than by those caused by Rhizopus stolonifer. 
Johnson and Case (1995) posited than an organism could be considered resistant if diameter of zone of inhibition is $<100 \mathrm{~mm}$, intermediate (moderately susceptible/ resistant) if diameter of zone of inhibition is between $11-15 \mathrm{~mm}$ and susceptible if the zone of inhibition is $>16 \mathrm{~mm}$. Going by this assertion, $60 \% \mathrm{~V}$. amygdalina aqueous extract and $40 \%$ ethanolic extratcs could be said to be very active against Aspergillus niger and Altermaria altermata while being moderately active against Rhizopus stolonifer. However, $60 \%$ ethanol extract is very active against all test fungi.

\section{Conclusion}

Aqueous and ethanolic extracts of $V$. amygdalina inhibited the growth of Aspergillus niger,Altermaria altermata and Rhizopus stolonifer. V. amygdalina $60 \%$ aqueous concentration, and $40 \%$ ethanolic concentration were considerably active against Aspergillus niger and Altermaria altermata while being moderately active against Rhizopus stolonifer. However, $60 \%$ ethanolic extracts was very active against all test fungi This botanical would serve as a viable alternative for chemical fungicides being readily available and possess little or no threat to our environment. It would be effective in the control of post harvest spoilage of tomato fruits in storage, especially spoilage occasioned by Aspergillus and Alternaria spp.

\section{Conflict of interest}

The authors declare that they have no conflict of interest.

\section{References}

AOAC - Association of Official Analytical Chemists. Official methods of analysis of AOAC International. 15. ed. Washington, D.C.: AOAC, 2005.

Adegoke, G. O.; Gbadamosi, R.; Evwoerhurhima, F.; Uzo-Peters, P.; Falade, K.; Itiola, O.; Moody, O.; Skura, B. Protection of maize (Zea mays) and Soybean (Glycine max) using Aframomum danielli. European Journal of Foods Research and Technology, v. 214, p. 408-411, 2002.

Agrios, G. N. Plant pathology. 5. ed. Cham: Elsevier Academic Press, 2005.

Al-Harbi, R.; Al-Wegaisi, R.; Moharram, F.; Shaaban, M.; El Rahman, O. A. Antibacterial and anti-hemolitictivity of tannins from Pimentadioica against methicillin resistant Staphylococcus aureus. Bangladesh Journal of Pharmacology, v. 12, p. 63-68, 2017.

Amadioha, A. C. Fungi toxic effect of some leaf extracts against Rhizopus oryzaecausing tuber rot of potato. Archives of Phytopathology and Plant Protection, v. 33, n. 6, p. 499-507, 2000. https://doi.org/10.1080/03235400109383372

Adetunji, C. 0.; Olaniyi, 0. O.; Ogunkunie, A. T. J. Bacterial activity of crude extracts of Vernonia amygdalina on clinical isolates. Journal of Microbiology and Anitimicrobials, v. 5, p. 60-64, 2013.

Audu, I.; Sanusi, S. B.; Linatoc, A. C.; Mainassara, M. M.; Awawu, J. J. Phytochemical analysis and actimicrobial activity of bitter leaf (Vernonia amygdalina) collected from Lepai, Niger State, Nigeria, on some selected pathogenic micro organisms. Science World Journal, v. 13, no. 3, p. 15-18, 2018.

Bai, Y.; Lindhout, P. Domestication and breeding of tomatoes: What have we gained and what can we gain in the future? Annals of Botany, v. 100, no. 5, p. 1085-1094, 2006. 
Bankole, S. A.; Joda A. O.; Ashidi J. S. The use of powder and essential oil of Cymbopogon citratus against mould deterioration and aflatoxin contamination of 'egusi' melon seeds. Journal of Basic Microbiology, v. 45, p. 20-30, 2005.

de Boer, H. J., Kool, A.; Broberg, A.; Mziray, W. R.; Hedberg, I.; Levenfors, J. J. Anti-fungal and anti-bacterial activity of some herbal remedies from Tanzania. Journal of Ethnopharmacology, 96, p. 461-469, 2005. https://doi.org/10.1016/j.jep.2004.09.035

Borguini, R. G.; Torres, E. A. F. S. Tomatoes and tomato products as dietary sources of antioxidants. Food Review International, v. 25, no. 4, p. 313-325, 2009. https://doi.org/10.1080/87559120903155859

Challand, S.; Wilcox, M. A clinical trail of the traditional medicine Vernonia amygdalina in the treatment of uncomplicated malaria. The Journal of Alternative Complementary Medicine, v. 15, no. 11, p. 1231-1237, 2009. https://doi.org/10.1089/acm.2009.0098

Chuku, E. C.; Emiri, U. N. Assessment of the proximate, phytochemical and antifungal potency of crude leaf extract of Asystasia gangetica. Nigeria Journal of Mycology, v. 11, p. 182-195, 2019.

Chuku, E. C.; Osakwe, J. A.; Daddy-West, C. Fungal spoilage of tomato (Lycopersicon esculentum) using garlic and ginger. Scientia Africana, v. 9, no. 2, p. 41-48, 2010.

Doughari, J. H.; Elmahmood, A. M.; Manzara, S. Studies on the antibacterial activity of root extracts of Carica papaya L. African Journal of Microbiology Research, v. 1, p. 37-41, 2007.

Doyle, M. Microbial food spoilage: Losses and control strategies. FRI BRIEFINGS, 2007. Available from: <https://fri.wisc.edu/files/Briefs_File/2017-07-18_0857_FRI_Brief_ Microbial_Food_Spoilage_7_07.pdf>. Accessed on: July 13, 2020.

Ebiowei, E.; Emiri, U. Post harvest quality of commercial Irvingia kernels and the potential use of Ocimum gratissimum (scent leaf) against fungal spoilage. Research Journal of Food Science and Quality Control, v. 2, no. 1, p. 1-11, 2016.

Etebu, E.; Nwauzoma, A. B; Bawo, D. D. S. Postharvest spoilage of tomato (Lycopersicum esculentum) and control strategies in Nigeria. Journal of Biology, Agriculture and Healthcare, v. 3, no. 10, p. 51-63, 2013.

Evangelia, M.; Stefania, O.; Gizzi, S.; Ruggero, R.; Stefano R. Passion flower fruit: A new source of lycopene? Journal of Medicine and Food, v. 81, no. 1, p. 104-106, 2005.

Feshola, M.; Merli, E.; Boncampagni, E.; Ranpa, A. Monitoring heron populations in Italy, 1972-2010. Journal of Heron Biology and Conservation, 1:8, 2011.

Ghosh, A. Identification of microorganisms responsible for spoilage of tomato (Lycopersicum esculentum) fruit. Journal of Phytology, v. 1, no. 6, p. 414-416, 2009.

Ijato, J. Y. Inhibitory effect of two indigenous plant extracts of Zingiber officinale and Ocimum gratissimum on post-harvest yam (Dioscorea rotundata) rot in vitro. Journal of American Science, v. 7, no. 1, p. 43-47, 2011.

Jasim, H.; Hussein, A. O.; Hameed, I. H. Characterization of alkaloid constitution and evaluation of antimicrobial activity of Solanum nigrum using gas chromatography mass spectrometry (GC-MS). Journal of Pharmacognosy and Phytotherapy, v. 7, p. 56-72, 2015.

Jin, Z.; Gao, L.; Zhang, L.; Liu, T.; Yu, F.; Zhang, Z.; Wang, B. Antimicrobial activity of saponins produced by two novel endophytic fungi from Panax notoginseng. Natural 
Product Research, $\quad$ v. 31 , p. 2700-2703, 2017. https://doi.org/10.1080/ 14786419.2017.1292265

John, W. C.; Anyanwu, N. C. J.; Ayisa, T. Evaluation of the extract o Vernonia amygdalina on fungi associated with infected tomatoes (Lycopersicum esculentum) in Jos North Local Government Area, Plateau State, Nigeria. Annual Research and Review in Biology, v. 9, no. 4, p. 1-8, 2016.

Johnson, T.; Case, C. Chemical methods of control, adopted from Laboratory Experiments in Microbiology: Brief edition. 4.ed. Redwood City, CA: Benjamin, Cummings Publishing, 2006.

Manczinger, L.; Antal, Z.; Kredics, L. Ecophysiology and breeding of mycoparasitic Truchoderma strains (a review). Acta Microbiologica et Immunologica Hungarica, v. 49, p. 1-14, 2002. https://doi.org/10.1556/amicr.49.2002.1.1

Moneruzzaman, K. M.; Hossain, A. B. M. S.; Sani, W.; Saiffudin, M. Effect of stages of maturity and ripening conditions on the biochemical characteristics of tomato. American Journal of Biochemistry and Biotechnology, v. 4, no. 4, p. 336-344, 2008.

Nenaah, G. Antimicrobial activity of Calotropis procera Ait. (Asclepiadaceae) and isolation of four flavonoid glycosides as the active constituents. World Journal of Microbial Biotechnol, v. 29, p. 1255-1262, 2013.

Okigbo, R. N.; Ikediugwu, F. E. O. Studies on biological control of post harvest rot of yam (Dioscorea spp) with Trichoderma viride. Journal of Phytopathology, v. 14, no. 8, p. 351$355,2000$.

Onyeani, C. A.; Osunlaja S. 0.; Oworu 0. O.; Joda A. O. Evaluation of effect of aqueous plant extract in the control of storage fungi. International Journal of Science Technology Research, v. 1, no. 6, p. 76-79, 2012.

Oshim, I. O.; Desmond, C. O.; Anyi, R.; Nwobu, U.; Ezugwu, U. M.; Umana, E. U. Kinetics of minimum inhibitory concentration, minimum bacterial concentration and minimum fungicidal concentration of Vernonia amygydalina (bitter leaf) on micro-organism isolates from wound infections. International Journal of Surgical Research, v. 5, p. 8-14, 2016.

Pessoa, L. M.; Morais, S. M.; Bevilaqua C. M. L.; Luciano J. H. S. Anthelmintic activity of essential oil of Ocimum gratissimum Linn. and eugenol against Haemomchus contortus. Veterinary Parasitology, v. 109, no. 1/2, p. 59-63, 2002. https://doi.org/10.1016/s03044017(02)00253-4

Ray, R. C.; Nedunzhiyan M.; Balangopalan, C. Micro-organisims associated with postharvest spoilage of yams. Annals of Tropical Research, v. 22, no. 1/2, p. 31-40, 2000.

Shidfar, F.; Froghifar, N.; Vafa, M.; Rajab, A.; Hosseini, S.; Shidfar, S.; Gohari, M. The effects of tomato consumption on serum glucose, apolipoprotein B, apolipoprotein A-I, homocysteine and blood pressure in type 2 diabetic patients. International Journal of Food Science and Nutrition, v. 62, no. 3, p. 289-294, 2010. https://doi.org/10.3109/ 09637486.2010 .529072

Suleiman, M. N.; Emua, S. A.; Taiga, A. Effect of aqueous leaf extracts on a spot fungus (Fusarium sp) isolated from cowpea. American-Eurasion Journal of Sustainable Agriculture, v. 2, no. 3, p. 261-263, 2008. 
Talvas, J.; Caris-veyrat, C.; Guy, L.; Rambeau, M.; Lyan, B.; Minet-Quinard, R.; Lobaccaro, J.M. A.; Vasson, M.-P.; Georgé, S.; Mazur, A.; Rock, E. Differential effects of lycopene consumed in tomato paste and lycopene in the form of a purified extract on target genes of cancer prostatic cells. American Journal of Clinical Nutrition, v. 91, no. 6, p. 1716-1724, 2010. https://doi.org/10.3945/ajcn.2009.28666

Udochukwu, U.; Omeje, F. I.; Uloma, I. S.; Oseiwe, F. D. Phytochemical analysis of Vernonia amygydalina and Ocimum gratissimum extracts and their antibacterial activity on some drug resistant bacteria. American Journal of Research Communication, v. 3, no. 5, p. 225-235, 2015.

Ugwu, O. C.; Chukwuezi, F. O.; Ozougwu, V. E. O. Microbial agents of tomato spoilage in Onitsha metropolis. Advances in Biological Research, v. 8, no. 2, p. 87-93, 2014.

Ugwuoke, K. I.; Onyeke, C. C.; Tsopmbeng, N. G. R. The efficacy of botanical protectants in the storage of cocoyam (Colocassia esculenta (L.) Shott). Agroscience Journal of Tropical Agriculture, Food Environment and Extension, v. 7, no. 2, p. 93-98, 2008.

WHO - World Health Organization. Reducing risks, promoting healthy life. Geneva: OMS, 2002. (World Health Report). Available from: <http://www.int/entity/whr/2002/ en/whr02_en.pdf >. Accessed on: Jan. 22, 2020.

Zdenka, P.; Peter, S.; Hana, D.; Milan, H. Antimutagenic effects of lycopene and tomato Puree. Journal of Medicine and Food, v. 13, no. 6, p. 1443-1450, 2010.

Zhang, C.-X.; Ho, S. C.; Chen, Y.-M.; Fu, J.-H.; Cheng, S.-Z.; Lin, F.-Y. Greater vegetable and fruit intake is associated with a lower risk of breast cancer among Chinese women. International Journal of Cancer, v. 125, no. 1, p.181-188, 2009. https://doi.org/ $10.1002 / \mathrm{ijc} .24358$

License information: This is an open-access article distributed under the terms of the Creative Commons Attribution License, which permits unrestricted use, distribution, and reproduction in any medium, provided the original work is properly cited. 